[Agr. Biol. Chem., Vol. 33, No. 4, p. 549 553, 1969]

\title{
A Protease Inhibitor from Penicillium cyclopium
}

\author{
Part II. Some Properties of the Inhibitor
}

\author{
By Kyo Shimada and Kin'ichi Matsushima
}

Department of Agricultural Chemistry, Mie University, Tsu

Received September 20, 1968

\begin{abstract}
Properties of a protease inhibitor from Penicillium cyclopium were studied. The $\mathrm{pH}$ range of the inhibitor action is restricted to acid $\mathrm{pH}$, optimally at $\mathrm{pH} 3$. Increasing temperature accelerates its action upon enzyme. The inhibitor causes enzyme inactivation in proportion to its concentration. It is fairly stable in an acid solution but unstable in an alkaline solution. It undergoes destruction by heat, hydrogen peroxide and ascorbic acid. The inhibitor reversibly combines with $\mathrm{Al}^{3+}, \mathrm{Fe}^{3+}, \mathrm{Ag}^{+}$and $\mathrm{Cu}^{2+}$ to produce a precipitate. Salts interfer with the inhibitor activity. Generally, acid proteases from various penicillia are susceptible to the inhibitor while those from other genera are resistant.
\end{abstract}

In a previous experiment ${ }^{11}$ the isolation and purification of a protease inhibitor from the extract of cultures of Penicillium cyclopium were performed. A floccose and hygroscopic substance, monodisperse in sedimentation analysis, was obtained as the purified inhibitor. The present report deals with some properties of this purified inhibitor.

\section{MATERIALS AND METHODS}

Purified inhibitor preparation. This was obtained by the procedures as described previously. ${ }^{11}$

Proteolytic enzymes. The acid protease of P. cyclopium was purified according to the procedures described previously.2) Pepsin and acid proteases from Aspergillus saito, A. niger, Penicillium notatum, and Paecilomyces varioti were the same as in a previous experiment. ${ }^{2)}$ Acid protease from Trametes sanguinea was furnished by Dr. K. Tomoda of the Takeda Yakuhin Kogyo Co. Acid proteases of other molds were prepared from extracts of cultures grown on wheat bran by means of fractionation with ammonium sulfate

1) K. Shimada and K. Matsushima, Agr. Biol. Chem., 33, 554 (1969).

2) Idem. Abstract of Papers, Annual Meeting of Agricultural Chemical Society of Japan, Nagoya, April, 1968. p. 205.
(40 80\% saturation) followed by gel filtration with Sephadex G-50. Trypsin was a product of Mochida Seiyaku Co., LTD.

Determination of protease activity. Protease activity was determined by the casein digestion method of Hagihara et al.31

Measurement of inhibitor. The assay of the activity of inhibitor was performed as reported previously $y^{4}$ using the above purified acid protease from $P$. cyclopium as substrate.

\section{RESULTS}

The activity of the inhibitor

Figure 1 shows the result of the experiment on the relation between the quantity of the inhibitor and the reduction of enzyme* activity. In agreement with the previous result using partially purified enzyme preparation, ${ }^{4)}$ the inactivation of enzyme appears to be proportional to the amount of inhibitor under the

3) B. Hagihara et al., J. Biochem. (Tokyo), 45, 185 (1958)

4) K. Shimada and K. Matsushima, Nippon Nogeikagaku Kaishi, 41, 454 (1967).

* In this text, purified acid protase from $P$. cyclopium is noted for short as "enzyme" 
test conditions. One micrograms of the purified inhibitor preparation was found to inhibit approximately 30 units of enzyme activity.

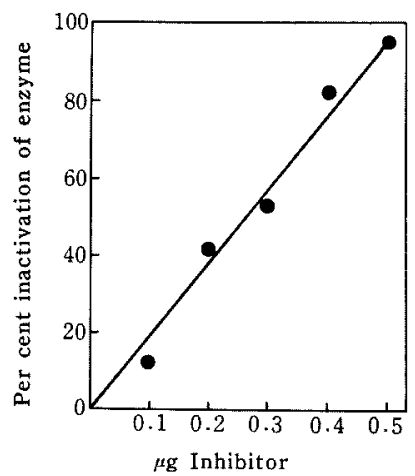

FIG. 1. The Relation between Quantity of Inhibitor and Inactivation of Enzyme.

Enzyme (15 units) was mixed with an indicated amount of inhibitor in $1 \mathrm{ml}$ of $0.05 \mathrm{M}$ sodium lactate buffer, $\mathrm{pH}$ 3.0. After the mixture was preincubated for $10 \mathrm{~min}$ at $40^{\circ} \mathrm{C}, 1 \mathrm{ml}$ of $2 \%$ casein was added and the remaining activity of enzyme was determined.

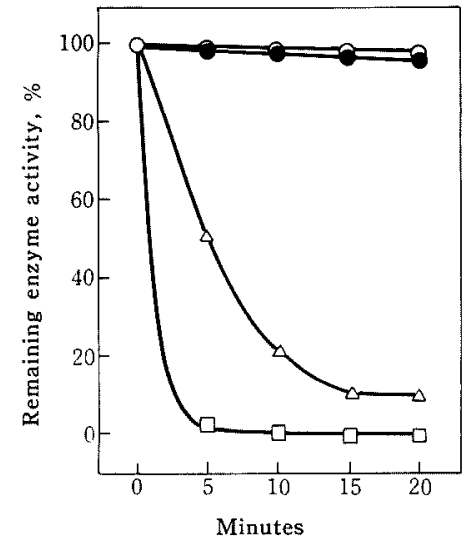

FIG. 2. The Effect of $\mathrm{pH}$ on the Rate of Inactivation of Enzyme by the Inhibitor.

The buffers used were $0.01 \mathrm{M}$ sodium lactate $(\mathrm{pH}$ $3.0 \sim 4.0)$ and $0.01 \mathrm{M}$ phosphate buffer $(\mathrm{pH} 5.0 \sim$ 6.0). Preincubation was carried out for indicated times with $15 \mu \mathrm{g}$ of enzyme and $3 \mu \mathrm{g}$ of inhibitor per $\mathrm{ml}$ of reaction mixture and then analyzed for the remaining enzyme activity by the standard

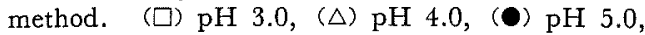
(O) $\mathrm{pH} 6.0$.

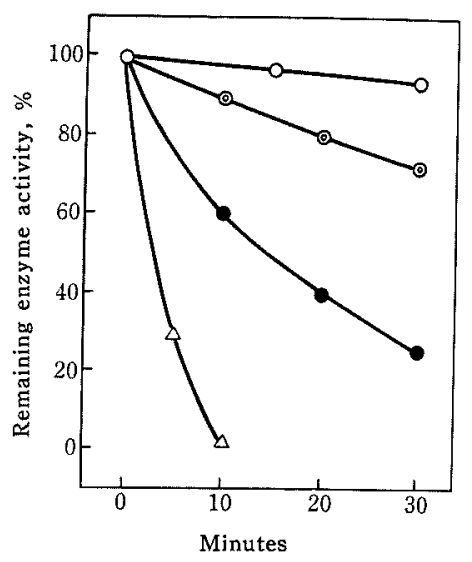

FIG. 3. The Effect of Temperature on the Rate of Inactivation of Enzyme by the Inhibitor.

Two hundred micrograms of enzyme and $10 \mu \mathrm{g}$ of the inhibitor was dissolved in $1 \mathrm{ml}$ of $0.05 \mathrm{M}$ sodium lactate buffer, $\mathrm{pH} 3.0$, and the mixture was held in a water bath of a specified temperature. At intervals, $1 \mathrm{ml}$ of $2 \%$ casein was added to the mixture and the remaining enzyme activity was determined. (O) $0^{\circ} \mathrm{C}$, () $10^{\circ} \mathrm{C}$, (-) $20^{\circ} \mathrm{C}$,

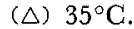

Effect of $p H$ and temperature on the activity of the inhibitor

As shown in Fig. 2, the inhibitor is active in solutions of acid $\mathrm{pHs,} \mathrm{optimally} \mathrm{at} \mathrm{pH} 3$, but inactive above $\mathrm{pH} 5$. The effect of temperature on the inhibitor activity is shown in Fig. 3. The enzyme can be incubated with the inhibitor without significant loss of activity at $0^{\circ} \mathrm{C}$ but increasing the incubation temperature stimulates the rate of enzyme inactivation; $10 \mathrm{~min}$ incubation at $35^{\circ} \mathrm{C}$ results in a complete inactivation under the test conditions.

Effect of $p H$ and heat on the stability of the inhibitor

The $\mathrm{pH}$ stability of the inhibitor was tested between $\mathrm{pH} 2.0$ and 9.0. The inhibitor was incubated at a given $\mathrm{pH}$ for one-half hour and then tested for the remaining activity. The result given in Fig. 4 indicates that the inhibitor is fairly stable in the range between 
pH 2 and 9 at $40^{\circ} \mathrm{C}$ while cosiderably unstable at alkaline $\mathrm{pH}$ at $50^{\circ} \mathrm{C}$.

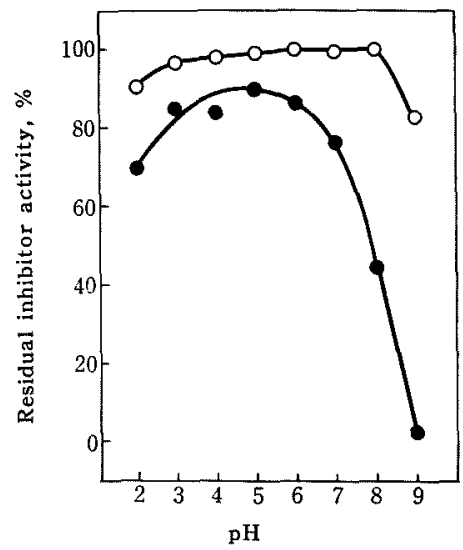

FIg. 4. The Effect of $\mathrm{pH}$ on Stability of the Inhibitor.

Buffers used were 0.1 M HCl-NaOAc $(\mathrm{pH} 2.0)$, $0.1 \mathrm{M}$ lactic acid-Na-lactate $(\mathrm{pH} 3.0 \sim 5.0)$, and 0.1 $\mathrm{M} \quad \mathrm{KH}_{2} \mathrm{PO}_{4}-0.05 \mathrm{M} \quad \mathrm{Na}_{2} \mathrm{~B}_{4} \mathrm{O}_{7}(\mathrm{pH} 6.0 \sim 9.0)$. One milligram of inhibitor was dissolved in $1 \mathrm{ml}$ of buffer and allowed to stand under a specified temperature. After one-half hour, the inhibitor solution was suitably diluted with $0.1 \mathrm{M}$ lactate buffer, pH 3.0, and portions of the diluted solution were analyzed for the remaining inhibitor activity. (O) at $40^{\circ} \mathrm{C},(\Theta)$ at $50^{\circ} \mathrm{C}$.

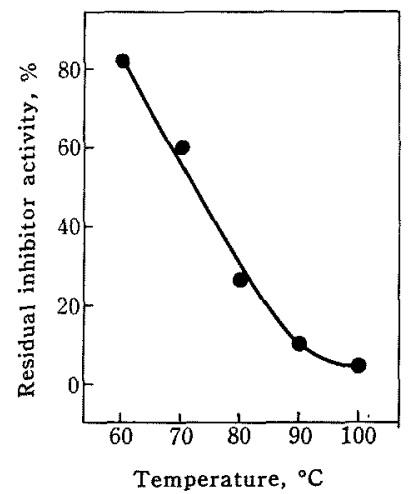

FIG. 5. Heat Inactivation of the Inhibitor.

A purified inhibitor preparation (150 units $/ \mathrm{ml}$ ) in $0.05 \mathrm{M}$ phosphate buffer ( $\mathrm{pH} 6.0$ ) was subjected to $10 \mathrm{~min}$ of heat treatment at the temperatures indicated. The activity remaining after the treatment is expressed as per cent of the initial activity.
The effect of heat on the stability of the inhibitor was determined by incubating the inhibitor at various temperatures for $10 \mathrm{~min}$. From the result presented in Fig. 5, it is evident that the inhibitor is sensitive to heat; partially destroyed between $60^{\circ} \mathrm{C}$ and $80^{\circ} \mathrm{C}$ and almost completely at $90^{\circ} \mathrm{C}$.

\section{Stability toward reducing and oxidizing agents}

The reducing agents employed were hydrogen sulfite, sodium sulfide and ascorbic acid, and the oxidizing agents hydrogen peroxide, sodium nitrite and sodium hypochlorite. As listed in

TABLE I. INFLUENCE OF REDUCING AND OXIDIZING AGENTS ON THE INHIBITOR

Reagents Concentration Remaining inhibitor

Reducing agents:

$\mathrm{H}_{2} \mathrm{~S}^{*}$

(M) activity, \%

$\mathrm{Na}_{2} \mathrm{SO}_{3}$

Ascorbic acid

0.01

86.4

76.4

31.1

Oxidizing rgents:

$\begin{array}{llr}\mathrm{H}_{2} \mathrm{O}_{2} & 0.01 & 5.0 \\ \mathrm{NaNO}_{2} & 0.01 & 95.0 \\ \mathrm{NaOCl} & 0.01 & 84.0\end{array}$

* Bubbled for $15 \mathrm{~min}$.

To $0.2 \mathrm{ml}$ of the inhibitor solution $(10 \mathrm{mg} / \mathrm{ml}, \mathrm{pH}$ 6.0) was added $0.2 \mathrm{ml}$ of reagent solution and incubated for $1.5 \mathrm{hr}$ at $35^{\circ} \mathrm{C}$. The mixture was then diluted with dist. water sufficiently enough to neglect the effect of reagent on enzyme which was used as substrate in the inhibitor assay. Control was run using dist. water instead of reagent.

Table I, the most effective agents were hydrogen peroxide and ascorbic acid. Sodium nitrite, sodium hypochlorite and hydrogen sulfite had no effect.

\section{Infuence of metallic salts on the inhibitor}

Table II is the result of the experiment on the influence of various metallic salts upon the inhibitor. It is seen from the Table that, of the metallic salts employed, alminium sulfate and ferric sulfate were most potent in diminishing the inhibitor activity and silver nitrate and cupric sulfate were also inhibitory 
in higher concentration. These compounds gave precipitates when mixed with the inhibitor solution, and the inhibitor could be recovered from the precipitate by washing it with ethylendiamintetraacetic acid or weakly alkaline solutions.

Table II. Influence of Metallic Salts ON THE INHIBITOR

$\begin{array}{ccc}\text { Metallic salts } & \begin{array}{c}\text { Concentration } \\ (\mathbf{M})\end{array} & \begin{array}{c}\text { Remaining inhibitor } \\ \text { activity, } \%\end{array} \\ \mathrm{NaCl} & 0.10 & 99.2 \\ \mathrm{MnSO}_{4} & 0.10 & 90.1 \\ \mathrm{ZnSO}_{4} & 0.10 & 82.0 \\ \mathrm{BaCl}_{2} & 0.10 & 90.8 \\ \mathrm{CaCl}_{2} & 0.10 & 84.3 \\ \mathrm{MgSO}_{4} & 0.10 & 89.6 \\ \mathrm{CoCl}_{2} & 0.10 & 79.2 \\ \mathrm{HgCl}_{2} & 0.01 & 68.0 \\ \mathrm{AgNO}_{3} & 0.01 & 68.0 \\ & 0.10 & 14.8 \\ \mathrm{CuSO}_{4} & 0.01 & 46.3 \\ & 0.10 & 14.5 \\ \mathrm{Al}_{2}\left(\mathrm{SO}_{4}\right)_{3} & 0.01 & 15.0 \\ \mathrm{Fe}_{2}\left(\mathrm{SO}_{4}\right)_{3} & 0.01 & 1.5\end{array}$

The experimental conditions were the same as in Table I, except for the incubation time of one-half hour.

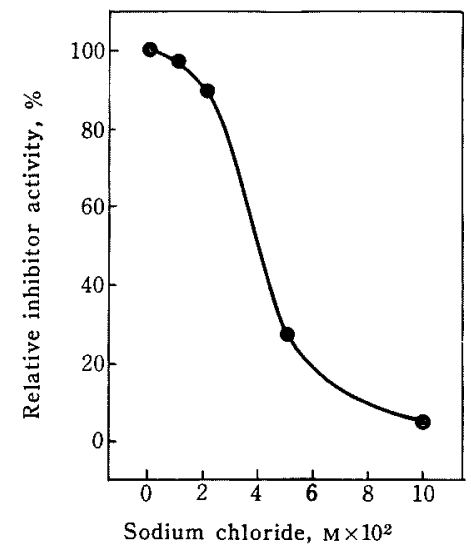

FIG. 6. Influence of Sodium Chloride on the Activity of the Inhibitor.

The system containing $2.5 \mu \mathrm{g}$ of inhibitor, 25 $\mu \mathrm{g}$ of enzyme and a given amount of $\mathrm{NaCl}$ in 1 $\mathrm{ml}$ of $0.05 \mathrm{M}$ lactate buffer $(\mathrm{pH} 3.0)$ was preincubated for $10 \mathrm{~min}$ at $35^{\circ} \mathrm{C}$ before analysis for the inhibitor activity.
Interference of salt with the inhibitor activity

During purification, we noticed that an inhibitor solution containing sodium chloride did not inhibit enzyme action inspite of its high concentration, while it did so when suitably diluted. This observation led us to investigate the influence of the presence of salt on the inhibitor activity. Figure 6 is a result

\section{Penicillium
chrysogenum \\ $P$. caseicolum \\ P. notatum \\ $P$. raistrickii \\ P. claviforme \\ P. cyaneo-fulvum \\ P. crustosum \\ P. ochraceum \\ P. citrinum \\ P. nigricans \\ P. granulatum \\ P. luteum \\ Rhizopis

$$
\text { formosensis }
$$ \\ R. oryzae \\ Aspergillus wentii \\ A. tamarii \\ A. flavus-oryzae \\ A. oryzae \\ A. usamii \\ A. awamorii \\ A. niger \\ A.niger (A) \\ A. niger $(\mathrm{B}$ ) \\ A. saitoi \\ Paecilomyces \\ Trametes sanguinea \\ Pepsin}

Trypsin

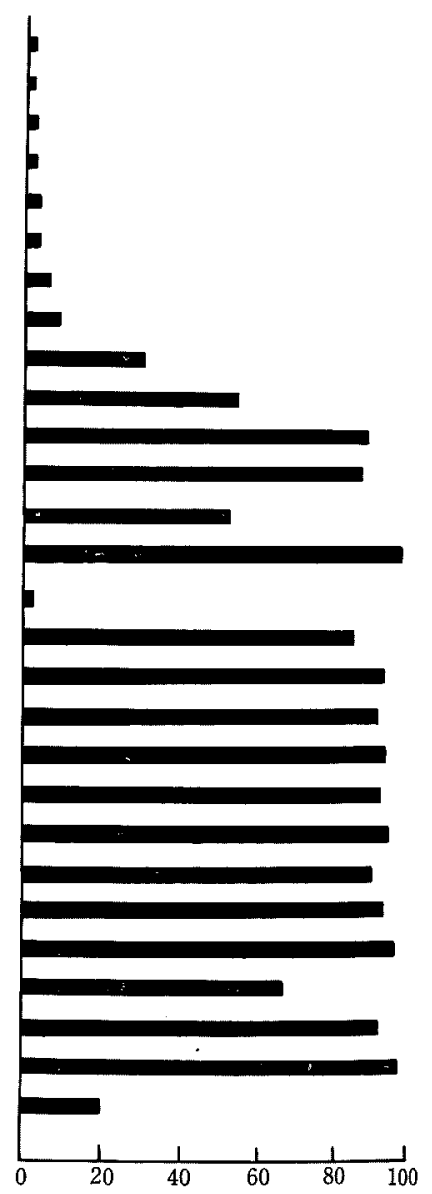

Origin of acid protease

FIG. 7. Action of Inhibitor on the Acid Protease from Various molds.

Enzyme (20 units) was mixed with $10 \mu \mathrm{g}$ of in-

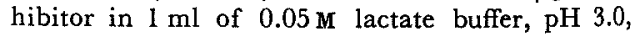
and incubated for $10 \mathrm{~min}$ at $40^{\circ} \mathrm{C}$. One milliliter of $2 \%$ casein was then added and analyzed for the remaining enzyme activity. 
of experiment on the influence of sodium chloride. The inhibitor activity was interfered with an increasing concentration of sodium chloride. Potassium chloride and ammonium chloride gave similar results.

The action of inhibitor on other proteolytic enzymes

The inhibitor has been shown to exert powerful action in destroying the activity of the acid protease of $P$. cyclopium. From the standpoint of comparative biochemistry, it was of interest to investigate its action on proteases from various origins. Acid proteases from different molds, pepsin and typsin were employed for this experiment, and the result is presented in Fig. 7. Acid proteases of penicillia, exceptions of $P$. granulatum and $P$. luteum, were found to be sensitive to the inhibitor, while those of other genera resistant to the inhibitor with the exception of $A$. wentii. Trypsin was inhibitor-sensitive. Pepsin was not sensitive.

\section{DISCUSSION}

A protease inhibitor produced by $P$. cyclopium was characterized as an acid, macromolecular substance. ${ }^{\prime \prime}$ The non-proteinous nature of the inhibitor has attracted our special attention since a variety of naturally occurring protease inhibitors known up to date are proteins. It seemed, therefore, worthwhile to study the properties of the inhibitor as well as its identity.

As reported ${ }^{4 \prime}$ previously, the inhibitor exhibits its inhibitory action only in solutions of acid $\mathrm{pH}$ values. It is optimally active at $\mathrm{pH}$ 3 while inactive at above $\mathrm{pH} 5$. From this we can understand the reason why enzyme in extract of mold's cultures, can remain active under the presence of the inhibitor. The inhibitor is fairly stable at acid $\mathrm{pH}$ values while readily destroyed in an alkaline solution.
On this nature, the neutralization to $\mathrm{pH} 4$ of eluate from Duolite A-2 column on a course of purification must be specially careful. Even at $\mathrm{pH} \mathrm{3,} \mathrm{which} \mathrm{is} \mathrm{optimal} \mathrm{for} \mathrm{the} \mathrm{inhibitor}$ action, enzyme can be incubated with the inhibitor for longer periods without severe loss of its activity as long as the mixture is kept at $0^{\circ} \mathrm{C}$. But the increase of the incubation temperature results in a increased rate of enzyme inactivation. The inhibitor is destroyed by heat, hydrogen peroxide, and ascorbic acid. It combines with aluminium-, ferric-, silver-, and cupric ions to produce precipitates. The combination between the inhibitor and these metallic ions seems to be reversible since the inhibitor can be recovered from the precipitate with ethylenediaminetetraacetic acid or weakly alkaline solutions. The presence of salt such as sodium chloride, potassium chloride and ammonium chloride interferes with the inhibitor action and, therefore, the reaction system must contain salt less than $0.02 \mathrm{M}$ concentration when the activity of the inhibitor is determined. The action of the inhibitor is not resticted upon the acid protease of $P$. cyclopium. Acid proteases of penicillia, with a few exceptions, are generally susceptible to the inhibitor, while those of other genera including Aspergillus, Rhizopus, Paecilomyces and Tremetes are generally highly resistant to the inhibitor. Thus, acid proteases of molds seem to be classified into two categories: "inhibitor-sensitive" proteases and "inhibitor-resistant" proteases. Trypsin can be included in the former and pepsin the latter.

Acknowledgements. The authors thank Dr. E. Ichshima of Kikkoman Shoyu Co., Dr. Y. Koaze of Meiji Seika Co., Dr. J. Sawada of Taisho Seiyaku Co., and Dr. K. Tomoda of Takeda Yakuhin Kogyo Co. for their kind supplies of purified acid proteases from molds. 